\title{
Repurchase intention behavior in B2C E-commerce
}

\section{Made Artana ${ }^{a}$, Hartina Fattah ${ }^{\mathrm{b}}$, I Gede Juliana Eka Putra ${ }^{\mathrm{a}}$, Ni Luh Putu Sarianic, Maryan Na- dir $^{\mathrm{d}}$, Asnawati ${ }^{\mathrm{d}}$ and Rismawati ${ }^{\mathrm{e}}$}

${ }^{a}$ College of Computer Management (STMIK) PRIMAKARA, Denpasar, Bali, Indonesia

${ }^{b}$ STAI YAPNAS Jeneponto Makassar, Sulawesi Selatan, Indonesia

${ }^{c}$ Universitas Pendidikan Nasional, Denpasar, Bali, Indonesia

${ }^{d}$ Program of Economic and Business Faculty, Mulawarman University Samarinda, East Kalimantan, Indonesia

Institute of Economic Science (STESIA), Surabaya, Indonesia

\section{H R O N I C L E}

Article history:

Received: June 18, 2021

Received in revised format: June

29,2021

Accepted: September 22, 2021

Available online: September 22 2021

Keywords:

Repurchases intention

e-commerce quality

Satisfaction

\section{A B S T R A C T}

\begin{abstract}
The intention to buy back is one of the objectives of the business strategy. This study aims to analyze the effect of mediating customer satisfaction on e-service and repurchase intention. This analytical study was conducted on e-commerce that is widely used by Indonesia, namely Shopee.co.id. The rapid growth of e-commerce, both $\mathrm{C} 2 \mathrm{C}$ and $\mathrm{B} 2 \mathrm{~B}$, has made online retailers compete in the online retail business. The intention to buy back is no longer solely due to the quality of service like an offline business. The purpose of this study is to analyze the role of mediating customer satisfaction from the quality of E-Commerce on repurchase intention in E-Commerce that has implemented a combination of $\mathrm{C} 2 \mathrm{~B}$ and $\mathrm{B} 2 \mathrm{~B}$. Quantitative methods with structural equation analysis (SEM) and path analysis were used to analyze data using LISREL. The questionnaire is distributed to respondents used as samples taken from the population for this research. The researched population is user of Shopee.co.id in Indonesia, whereas samples of the population are randomly taken. The samples of this research are 279 respondents. The results of this study found that there is no significant direct effect of electronic service quality on repurchases intentions, but when customer satisfaction acts as a mediating variable, it shows that electronic service quality affects repurchase intention significantly through customer satisfaction. This study will help online retailers to find out what factors influence customers to make repeat purchases.
\end{abstract}

\section{Introduction}

Shopee is a Singaporean e-commerce platform headquartered under Sea Group (previously known as Garena), which is a global consumer internet company founded in 2015. One of the online retailers in Indonesia is shopee.co.id coming to Indonesia in 2020. Shopee.co.id is a relatively new player. Shopee.co.id is an online retailer coming from Singapore and becoming a branch of shopee.co.id in Indonesia. Shopee.co.id is one of online retailers in Indonesia using a B2C business model. In 2020 a new online retail in Indonesia contributed 9\% of total sales in Indonesia (Driver et al. 2020). McKinsey also said that digital buyers or online buyers in Indonesia were about 30 million people in 2020 or only $11 \%$ of the total population of Indonesia. If compared to the internet users, which were 160 million, then Indonesia is highly potential to be the world's largest e-commerce. Indonesia is a populous country with more than 350 residents (bps.go.id, 2020). 160 million of them have access to the internet (Datareportal.com, 2020). Shopee.co.id becomes an e-commerce interesting to study because only within less than two years of operation, Shopee.co.id has successfully become $2^{\text {nd }}$ rank B2C online retailer by number of visits. This is surely an

* Corresponding author

E-mail address: artanaprimakara09@gmail.com (I M. Artana)

(C) 2022 by the authors; licensee Growing Science, Canada. doi: $10.5267 /$ j.ijdns. 2021.9 .013 
outstanding achievement considering the number of e-commerce companies operating in Indonesia. In addition, thereto, Shopee.co.id has explicitly said that one of their main strategies in e-commerce business is by continuously improving service quality to the customers. According to them, service quality to the customers is more important than discount (Song et al., 2020; Al-dweeri et al., 2019).

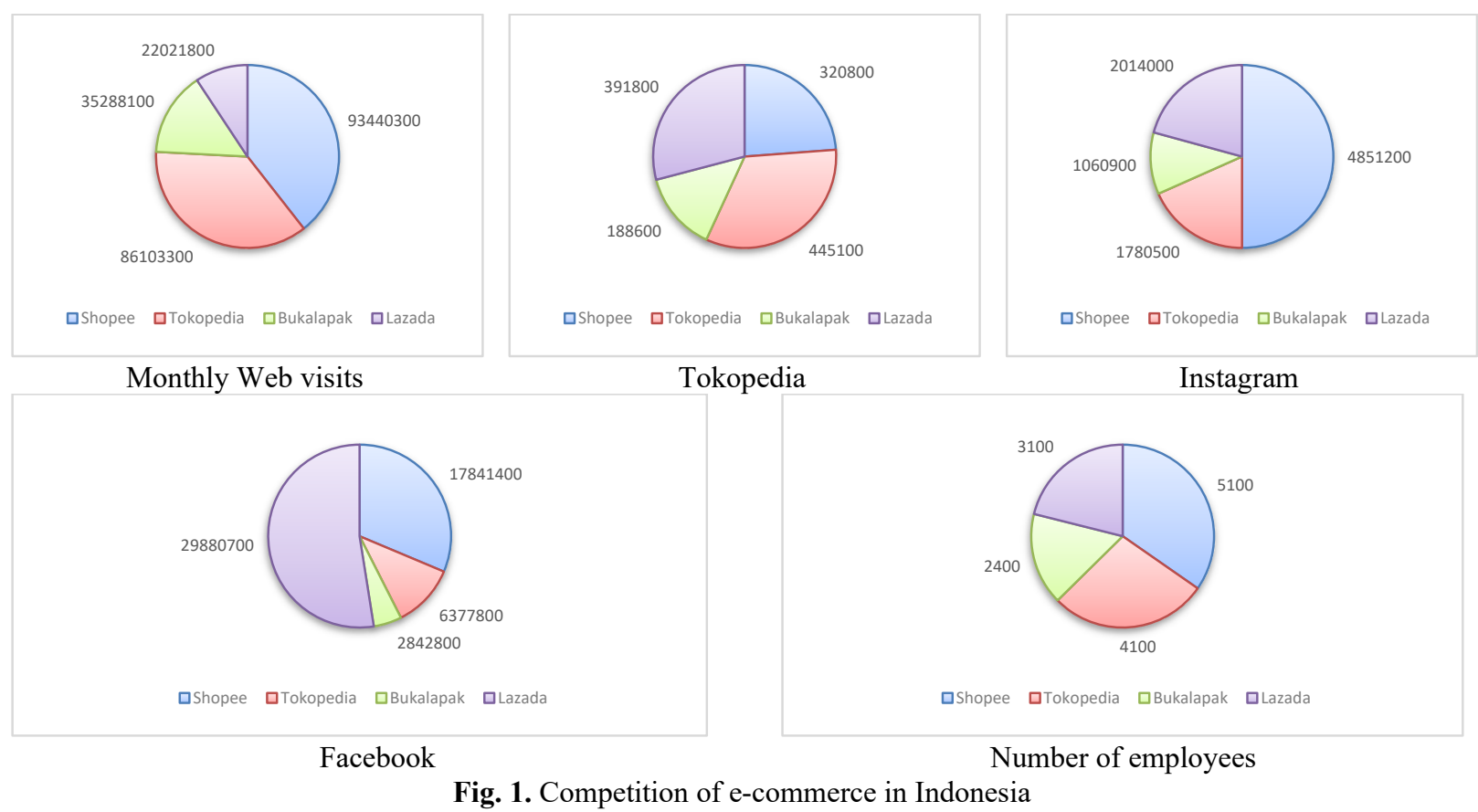

To have the option to continue contending with other online retailers and get a piece of the pie, Shopee.co.id needs to have techniques. One of the methodologies normally taken by Shopee.co.id to continue contending is by keeping up existing clients because keeping up with them is a significant issue in online retail business (Goutam, \& Gopalakrishna, 2018). Repurchase intention is customer behavior giving a positive response to e-service quality of a company and showing intention to revisit and consume the company's product (Spyridou, 2017). In the context of online retail (Goutam \& Gopalakrishna, 2018). Defines repurchase intention as the use of an online retailer to buy goods/service repeatedly. Now, repurchase intention has become an important issue for B2C e-commerce companies (Liu, 2012; Wang \& Teo, 2020). One of efforts that can be done by Shopee.co.id to increase the number of repurchases is by improving its service quality in order to satisfy customers. Service quality is one of important factors for the company to obtain competitive advantage (Liu, 2012; Wang \& Teo, 2020). Spyridou (2017) defines e-service quality as an assessment made thoroughly by customers on excellence and quality of eservice in the virtual marketplace.

Wang \& Teo (2020) explains service quality of online stores as an interactive, content oriented and internet-based customer service promoted by customer and integrated with technology and system offered by the service provider aimed at strengthening the relationship with customers. This explanation emphasizes that e-service quality of an online store/retailer highly depends on experience in using a website or application felt by the customers. Therefore, to support the strategy of Shopee.co.id in improving its service, it must find out the type of service the customers expect and whether good service quality can increase customer intention to repurchase. In addition, thereto, it must be found out also to what extent the service quality affects customer satisfaction. Previous studies show that e-service quality does affect customer satisfaction (Suhartanto et al., 2020; Candra \& Juliani, 2018) Customer satisfaction is feeling being satisfied or disappointed felt by customers when they receive a service and compared it to their expectation (Kotler, 2000). If the service is the same as or more than their expectation, they will be satisfied, on the contrary, if the service is not as their expectation, they will be disappointed. Several studies show that customer satisfaction has a role as mediator between E-service Qualities and repurchase intention (Kalia et al., 2016). Wilson et al. (2019) show that customer satisfaction has no significant role in mediating the relation between service quality and repurchase intention. The study is used as reference by the researcher in the replicating analysis model used.

Based on the previous studies a fore said, it seems that E-service quality affects repurchase intention and customer satisfaction. While customer satisfaction affects repurchase intention because satisfied customers will tend to repurchase and do positive word of mouth (Sullivan \& Kim, 2018). Therefore, the purpose of this study is to analyze the relation and effect of e-service quality to repurchase intention through customer satisfaction. In addition, thereto, this study also analyzes the interrelation between the variables. Does e-service quality have a direct effect on repurchase intention? How customer satisfaction affects repurchase intention? 


\section{Literature review}

Online repurchase intention is often discussed comprehensively by marketing researchers. Lin et al. (2017) express an opinion that repurchase is a deliberate behavior because customers usually have more than one store option to shop. In the context of online retail, Lin et al. (2017) define repurchase intention as the use of an online retailer to purchase goods/service repeatedly. Now, repurchase intention has become an important issue for the e-commerce industry.

According to Liu (2012), repeat customers are the source of profit for e-commerce companies because they tend to be not sensitive to price and they have bigger allocated funds. In addition, thereto, according to Liu (2012) also, the cost to serve the repeat customers is lower than the cost to acquire new customers and another benefit thereof is that repeat customers can affect others by giving positive recommendation.

Service quality is an important factor for a company to achieve differential advantage, namely differentiating a service provider from other service providers (Liu, 2012). In the last several years, interest in service quality has been shifted into interest to E-Service Quality at e-commerce companies (Liu, 2012).

Parasuraman et al. (2005) developed E-S-QUAL or E-Service Quality scale to assess service quality at online retailers. In carrying out the study, Parasuraman tried developing a special measuring scale for website or Electronic Service quality. The scale had four dimensions, namely:

- Efficiency dimension defined as easiness and speed in accessing and using the site.

- Fulfillment dimension defined as a condition to what extent an online retailer can fulfill its promise with respect to delivery and goods availability.

- System Availability dimension relating to the website functioning properly and correctly.

- Privacy dimension relating to security and confidentiality of customer personal information.

According to Kotler (2005), customer satisfaction is the feeling of being happy or disappointed felt by customers after comparing performance of a product or service to the expected performance. It means whether the customer is feeling happy and satisfied after ordering and buying the goods or service or disappointed after the purchase. If the customer feels happy and is satisfied after the purchase, then it can be concluded that the company has successfully satisfied the customer. On the contrary, if the customer feels disappointed after the purchase, then the company has failed to render high quality service.

Satisfaction is the Consumer's Fulfillment response, it is a judgment that product or service feature, or the product or service itself, provides a pleasurable level of consumption-related Fulfillment according by Firdous and Farooqi (2017).

\subsection{The relation of E-Service Quality to Repurchase Intention}

In her study, Liu (2012) found that E-Service Quality positively affects repurchase intention. Gupta and Kim (2007) in Liu (2012) said that easiness in online shopping significantly affects repurchase intention. Candra and Juliani (2018) had an opinion that in the traditional context, there were many studies measuring the effect and relation of E-Service Quality to repurchase intention. The studies identified an existing direct relation of the two concepts to E-Service Quality as proven by the studies that they affected repurchase intention. (Candra \& Juliani, 2018) in their study found that E-Service Quality positively affected repurchase intention. In addition, thereto, Wilson et al. (2019) and Giantari et al. (2021) in their studies found that service quality significantly affected repurchase intention. The study carried out by Wilson et al. (2019) is then used by the researcher in a replicating analysis model (Davison, 2017).

\subsection{The relation of Customer Satisfaction to Repurchase Intention}

Candra and Juliani (2018) in their study found that customer satisfaction affected repurchase intention. According to them, the study finding was in line with previous studies on e-commerce and indicated a positive effect of customer satisfaction to repurchase intention. In addition, thereto, the study finding was also in line and consistent with currently existing opinions with respect to the relation of the two concepts in traditional business whereas customer satisfaction, with various attributes of product or service usage, positively affect repurchase intention. Wilson et al. (2019) and Miandari et al. (2021) in their studies concluded that customer satisfaction significantly affected repurchase intention. Moreover, they found that customer satisfaction had a major contribution in its model. It indicates a strong effect of customer satisfaction to repurchase intention.

\subsection{The relation of E-Service Quality to Customer satisfaction}

A study previously carried out shows that E-Service Quality affects customer satisfaction. One of studies identifying a relation between the two variables was carried out by Candra and Juliani (2018) Their study concludes that if customers feel or deem that they have been given excellent service, then the feeling of being satisfied will be felt by the customers. Liu (2012) in her study found that the dimensions establishing E-Service Quality have a significant effect to customer satisfaction. The study carried out by Liu (2012) is consistent and in line with a study previously carried out by Collier and Bienstock (2006) concluding that in marketing, E-Service Quality is used to achieve customer satisfaction. A study carried out by Santouridis et 
al., (2014) shows that if the relation is direct in nature, E-Service Quality insignificantly affects customer satisfaction. A study also identifying an existing relation between the two variables was carried out by Wilson et al. (2019). They found that service quality significantly affects customer satisfaction.

\subsection{The relation of E-Service Quality to repurchase intention through Customer satisfaction}

Kalia, Arora and Kumalo (2016) in their study found an existing relation between E-Service Quality and repurchase intention through Customer satisfaction. Moreover, they found that Customer satisfaction has a role as mediator between E-Service Quality and future purchase intention. A good E-Service Quality would make customers satisfied (Fornell, 1992) and the satisfied customer tended to do positive word of mouth and repurchase (Kim, 2005). In addition (Suhartanto et al., 2020) in their study found that E-Service Quality had significant indirect effect, namely through Customer satisfaction, to repurchase intention. Wilson et al. (2019) had a different conclusion with respect to the relation between service quality, customer satisfaction and repurchase intention. Their study showed that even though there was a significant direct effect of service quality to repurchase intention, customer satisfaction did not moderate the effect of service quality to repurchase intention.

\section{Method}

This study is categorized as quantitative research using explanatory research aimed at analyzing the relation between variables and the effect of one variable to the other. Based on time dimension, the study is categorized as cross-sectional research aimed at identifying the relation of several variables to study, in particular number of samples and data taken within a short period. In this study, the researcher uses a questionnaire as the research instrument to obtain primary data. To get secondary data, the researcher carries out reference study from theoretical books, research journals and the internet. The questionnaire is distributed to respondents used as samples taken from the population for this research. The researched population is user of the Shopee.co.id in Indonesia, whereas samples of the population are randomly taken. The samples of this research are 279 respondents. The number of samples is determined based on the number of research indicators. According to Kumar et al. (2020), for data analysis method of structural equation modeling, the number of samples is five times of the number of indicators. Majority respondents for this research are university students especially those studying at University of Indonesia. Fig. 2 shows personal characteristics of the participants in our survey.

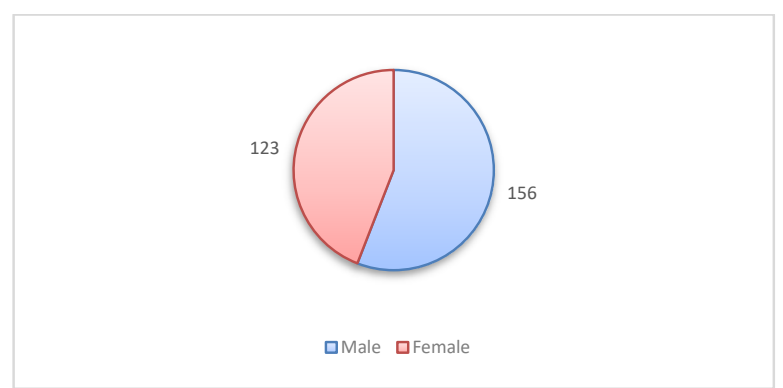

Gender

Fig. 2. Personal characteristics of the participants

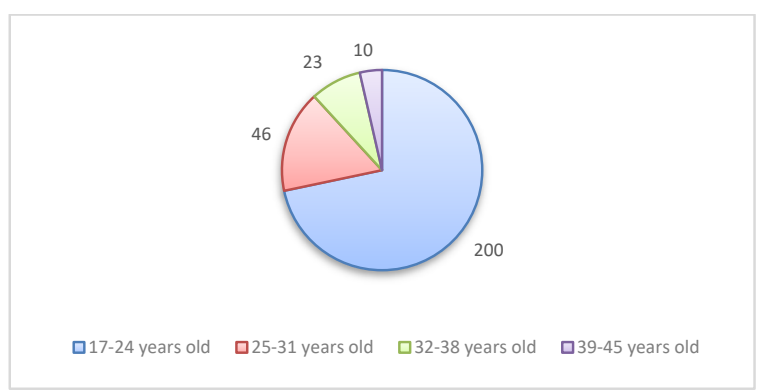

Age

Validity test is carried out by suing factor analysis. In this test, the researcher finds value of KMO Measure of sampling adequacy that is higher than 0.5. In addition, the researcher also finds value of Bartlett's of Sphericity that is lower than 0.05 . If meeting the two criteria, the indicator is stated sufficient to continue. Whereas for the reliability test, the researcher finds value of Cronbach's Alpha that is higher than 0.6.

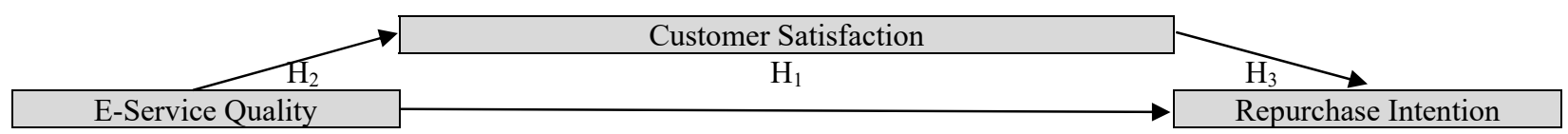

Fig. 3. Conceptual framework (Wilson et al., 2019)

\subsection{Hypothesis Development}

Based on the foregoing model, the hypothesis of this research is:

$\mathbf{H}_{1}$ : There is the effect of e-service quality to repurchase intention.

H2: There is the effect of e-service quality to customer satisfaction.

$\mathbf{H}_{3}$ : There is the effect of Customer satisfaction to Repurchase Intention. 
From the existing e-service quality measuring scales, the writer selects Efficiency, Fulfillment, System Availability and Privacy dimensions. The four dimensions are taken from an e-service quality measuring scale developed by Parasuraman, Zeithaml and Maholtra (2005). In this Variable, the researcher uses 24 items or indicators to measure E-Service Quality. Whereas for Repurchase Intention and Customer Satisfaction variable, the researcher uses the indicator from Liu (2012), Candra and Juliani (2018) and Parasuraman (2005). Each variable has four indicators to measure the variable. Total items or indicators in this research are 31 indicators. In accordance with the model developed in this research, the data analysis tool used is SEM (Structural Equation Modeling). The structural model describes the existing relations amongst latent variables. Whereas for a measuring model, to show a variable is latent in nature, it is measured by one or more variables using CFA Model (Confirmatory Factor Analysis). For data analysis of the SEM, the researcher uses LISREL 8.8 software.

\section{Result and Discussion}

Based on the validity test by using SPSS 22, the following result is obtained.

Table 1

The Result of Validity and Reliability Tests

\begin{tabular}{lccc}
\hline Dimension & Cronbach's Alpha $(>0.60)$ & KMO-Measure of Sampling Adequacy $(>0.5)$ & Bartlett's Test of Sphericity $(<0.05)$ \\
\hline Efficiency & 0.976 & 0.760 & 0.000 \\
System Availability & 0.777 & 0.560 & 0.000 \\
Fulfillment & 0.867 & 0.709 & 0.000 \\
Privacy and Security & 0.935 & 0.655 & 0.000 \\
Repurchase Intention & 0.879 & 0.666 & 0.000 \\
Customer Satisfaction & 0.875 & 0.567 & 0.000 \\
\hline
\end{tabular}

The foregoing table indicates that all indicators have good validity and reliability because they have fulfilled values and standards already determined. In Fig. 4, the relation of e-service quality to repurchase intention has t-value lower than 1.96. In addition, according to the calculation result, CR is higher than 0.70. Whereas there is VE value of Customer Satisfaction variable less than 0.50 but it is not an issue because CR Customer Satisfaction is higher than 0.6. It indicates that all indicators have good validity.

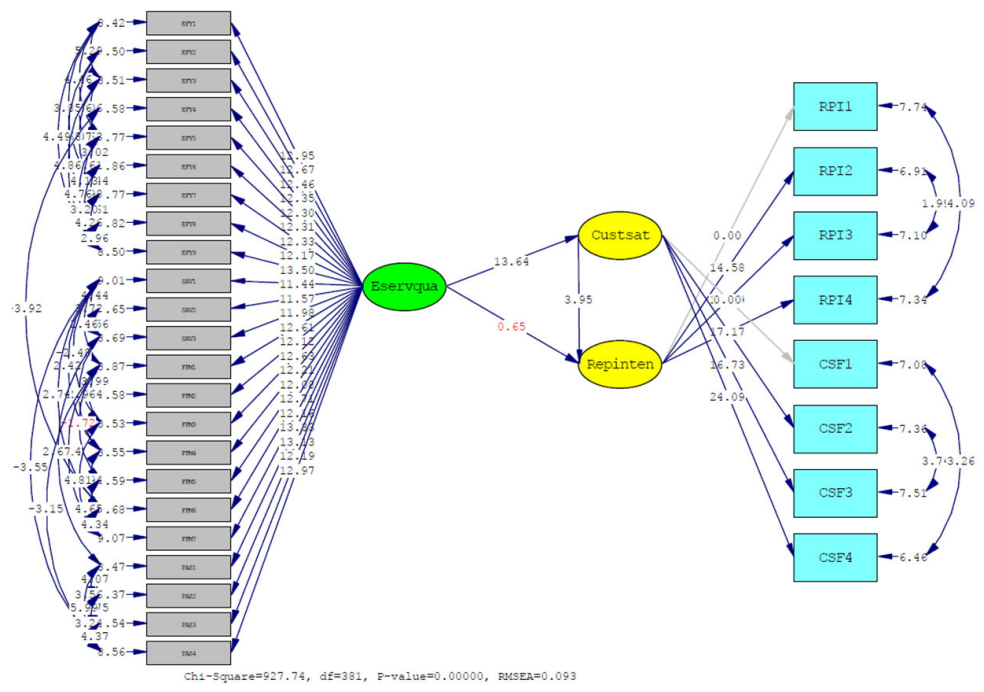

Fig. 4. Overall Model (t-value)

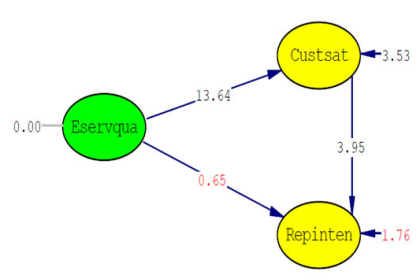

Fig. 5. Causal Relation

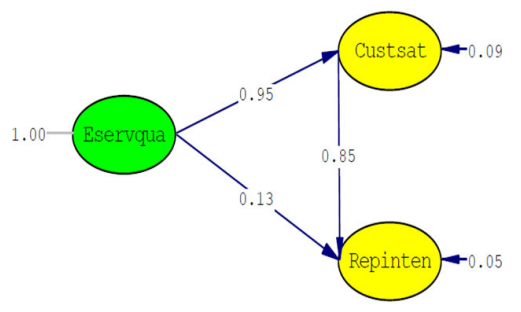

Fig. 6. Standardized Loading Factor

In addition, in order to measure model suitability, GOFI (Goodness of Fit index) calculation is carried out. The research model has GFI $=0.73$; RMSEA $=0.093$; NFI $=0.97$; CFI $=0.98 ; \mathrm{RFI}=0.97$; AGI $=0.65$. Majority of suitability score has fulfilled the criteria even there are remaining thereof still not fulfilling the requirement. The structural model in figure 2 above shows the relation amongst variables. T-value $\geq 1.96$ is used as condition for the hypothesis having positive effect and t-value $\leq$ 1.96 is used as condition for the hypothesis having negative effect, the path coefficient of the structural equation can be concluded significant, and the hypothesis is accepted. On the contrary, if t-value $<1.96$ or $>-1.96$, then it can be concluded that there is no significant effect amongst the latent variables (Kumar et al., 2020). 
Table 2

Conclusion of the Structural Model Significance

\begin{tabular}{lllll}
\hline & Path & Estimation & T-Value & Conclusion \\
\hline $\mathbf{1}$ & E-Service Quality to Repurchase intention & 0.13 & 0.65 & Insignificant \\
$\mathbf{2}$ & E-Service Quality to Customer satisfaction & 0.95 & 13.64 & Significant \\
$\mathbf{3}$ & Customer satisfaction to Repurchase intention & 0.85 & 3.95 & Significant \\
\hline
\end{tabular}

Based on the foregoing table, all path coefficients are significant unless the path from e-service quality to repurchase intention. The significance level can be seen from t-value higher than 1.96. The effect of E-Service Quality (Eservqua) to Repurchase Intention (Reprint) has a determination coefficient $\mathrm{R}^{2}=0.13$. It means that $13 \%$ variance of Repurchase Intention can be described by E-Service Quality (Eservqua) while the remaining 87\% variance is described by other factors. The effect of EService Quality (Eservqua) to Customer satisfaction (Custsat) has a determination coefficient $\mathrm{R}^{2}=095$. It means that EService Quality (Eservqua) describes 95\% variance of Customer satisfaction (Custsat) while the remaining 5\% variance comes from Customer Satisfaction (Custsat) can be described by other factors.

Table 3

Path Analysis

\begin{tabular}{llll}
\hline Relation amongst Variables & Direct Effect & Indirect Effect & Total Effect \\
\hline E-Service Quality $\rightarrow$ Repurchase Intention & 0.22 & 0.85 & 0.97 \\
E-Service Quality $\rightarrow$ Customer satisfaction & 0.96 & & \\
Customer satisfaction $\rightarrow$ Repurchase Intention & 0.97 & & \\
\hline
\end{tabular}

The foregoing table describes direct and indirect effects amongst variables in the research. The indirect effect describes the relation between E-Service Quality and Repurchase Intention variables mediated by Customer satisfaction variables. The direct effect of this research indicates that E-Service Quality has a significant, direct effect to Customer satisfaction. Customer satisfaction also has a significant, direct effect on Repurchase Intention. E-Service Quality does not have a significant, direct effect on Repurchase Intention. However, E-Service Quality has an indirect effect on Repurchase Intention. It is due to existing mediation by Customer satisfaction. When it is mediated by Customer satisfaction, E-Service Quality has a significant effect on Repurchase Intention (Amjad-ur-Rehman et al., 2019).

\section{Conclusion and Suggestion}

\section{$\mathbf{H}_{1}$ : There is the effect of E-Service Quality to Repurchase Intention.}

In light of the information preparing yield, it may very well be seen that the t-estimation of H1 is 0.65 . The worth is lower than basic t-estimation of 1.96, in this manner, the speculation is dismissed. The theory has a direct impact of 0.13 . It implies that E-Service Quality influences repurchase expectation at $13 \%$ and the remaining $87 \%$ is because of different components. The exploration shows a distinctive outcome contrasted with past investigations alluded to by the analyst. Liu (2012) in her exploration found that E-Service Quality decidedly influenced repurchase goals. Gupta and Kim (2007) in Liu (2012) said that effectiveness in web based shopping, for this situation included into E-Service Quality, had a huge impact on repurchase expectation. Candra and Juliani (2018) in their examination found that E-Service Quality decidedly influenced repurchase expectation. They likewise said that their examination demonstrated a decent help quality would add to expanding social expectations of clients, for example, returning to the site, repurchase, positive verbal exchange and lessening the chance of moving to another internet business. In accordance with the two investigations previously mentioned, Wilson, Keni and Tan (2019) additionally found that administration quality had a critical impact to repurchase aim.

\section{$\mathbf{H}_{2}$ : There is the effect of E-Service Quality to Customer satisfaction.}

Based on data processing output, it can be seen that the t-value of $\mathrm{H} 2$ is 13.64. The value is higher than 1.96, therefore, the hypothesis is acceptable. The hypothesis has a direct effect of 0.95 . It means that E-Service Quality effects customer satisfaction as much as $95 \%$ and the remaining $5 \%$ is affected by other factors. The data processing output of this hypothesis is also in line with several studies previously carried out. One of the studies finding the relation between the two variables is research carried out by Candra and Juliani (2018). Liu (2012) in his research found that dimensions establishing E-Service Quality had a significant effect to customer satisfaction. The research carried out by Liu (2012) was consistent and in line with research previously carried out by Collier and Bienstock (2006) concluding that in marketing, E-Service Quality is used to achieve customer satisfaction. Therefore, the hypothesis of this research supports the research carried out by Liu (2012) and Candra \& Juliani (2018). The result of this research supports the result of research carried out by Wilson et al. (2019) concluding that service quality significantly affected customer satisfaction.

\section{H3: There is effect of Customer satisfaction to repurchase intention.}

The data processing output of this hypothesis is also in line with several studies previously carried out. Candra and Juliani (2018) in their research found that customer satisfaction affected repurchase intention. According to them, the research finding 
was in line with previous research on e-commerce and indicated an existing positive effect of customer satisfaction to repurchase intention. Liu (2012) in her research found an existing significant, positive effect of customer satisfaction to repurchase intention. According to Liu, the research finding was in line with previous research finding that customer satisfaction positively and significantly affected repurchase intention. Moreover, according to Liu, the research successfully supported previous research and indicated that customer satisfaction was one of the main factors resulting in repurchase intention. Lin et al. (2017) specifically said that in the context of e-commerce, customers tend to shop on the same e-commerce website when they feel satisfied with the e-commerce website. In addition, Wilson et al. (2019) in their research also said that customer satisfaction had a significant effect to repurchase intention. Therefore, this hypothesis supports the research carried out by Candra \& Juliani (2018), Wilson, Keni \& Tan (2019) and Liu (2012); Wang \& Teo (2020).

\section{$\mathbf{H}_{4}$ : The effect of E-Service Quality to Repurchase Intention through Customer satisfaction.}

After the ascending of consumer loyalty having a capacity as arbiter, the circuitous impact estimation of E-Service Quality to repurchase goal increments to 0.81 . It shows that the consumer loyalty variable has a job as a middle person in this examination model. The condition is in accordance with past explorations alluded to by the specialist. Candra and Juliani (2018) found that E-Service Quality emphatically influenced Customer fulfillment and social expectations of clients. Furthermore, they likewise found that Customer fulfillment becomes a middle person between E-Service Quality and conduct goal (in which repurchase aim and informality exist). Likewise, Suhartanto et al. (2020) in their exploration found that E-Service Quality has critical backhanded impact, through Customer fulfillment, to repurchase goals. Kalia et al. (2016) in their research found an existing relation between E-Service Quality and repurchase intention through Customer satisfaction. Moreover, they also found that Customer satisfaction had a role as mediator between E-Service Quality and future purchase intention (Ali \& Bhasin, 2019). A good E-Service Quality would satisfy customers (Fornell, 1992) and the satisfied customers tended to do positive word of mouth and repurchase (Kim, 2005). Wilson et al. (2019) in their research found that customer satisfaction did not have any effect and function as a mediating variable in the relation between service quality and repurchase intention (Bressolles \& Nantel, 2008). The after effect of this investigation shows that E-service quality emphatically influences consumer loyalty. The finding is in accordance with a few past explorations additionally finding that E-service quality has critical, beneficial outcomes to consumer loyalty. The consequence of this examination can be utilized as one of references or considered by Shopee.co.id in planning its business technique. A prime assistance quality will make clients fulfilled and cheerful while purchasing at Shopee.co.id Therefore, Shopee.co.id is required to continue improving its E-service quality so as to make the clients fulfilled. This investigation additionally discovers that -service quality by implication influences repurchase expectation. The aberrant impact happens when it is intervened by consumer loyalty. A prime assistance quality, in this examination, can influence clients to repurchase items from Shopee.co.id the request is the point at which the clients get served by Shopee.co.id they will survey the administration delivered and contrast it with their desire. In the event that the clients feel that the administration they get is equivalent to or more than their desire, the clients will feel fulfilled and glad to shop at Shopee.co.id When the client feel fulfilled to and content with their choice shopping at Shopee.co.id the clients will settle on the choice to repurchase the item or E-service from Shopee.co.id. As per the reason for this examination, specifically to break down the impact of E-Service Quality to repurchase expectation through Customer fulfillment on clients of Shopee.co.id in Bali, the finishes of this investigation is made by the author:

1. E-Service Quality doesn't have an important effect on the repurchase point of customers of Shopee.co.id in Bali. The delayed consequence of this examination exhibits that a fair assistance quality won't thus cause the customers to hope to repurchase at di Shopee.co.id.

2. E-Service Quality has critical, helpful results to Customer satisfaction on customers of Shopee.co.id in Bali. It exhibits that when Shopee.co.id renders a prime assistance, it will manufacture customer devotion at Shopee.co.id

3. Customer satisfaction has tremendous, useful results to repurchase desire for customers of Shopee.co.id in Bali. It infers that buyer steadfastness is one of components affecting customer objective to repurchase at Shopee.co.id the more customers feeling content with Shopee.co.id the more grounded point of the customers to repurchase at Shopee.co.id

4. The result of this assessment shows that the organization nature of Shopee.co.id has basic, useful results to repurchase desire at whatever point mediated by buyer steadfastness. It suggests that E-Service Quality has an enormous effect on repurchase desire at whatever point intervened by customer steadfastness.

In the wake of preparing the information, translation and bringing about the end, the specialist has a few suggestions both for the professional for this situation the organization or for academicians.

1. A great help quality won't just make the clients glad and fulfilled however it will likewise cause them to choose to repurchase. It ought to be noted by advertiser and expert that so as to make the client repurchase, the issue that must be first noted is by giving them the best assistance so they feel fulfilled. At the point when the clients feel fulfilled, as per this investigation and the past examinations, they will consider repurchasing.

2. The exploration model just investigates the impact of administration quality to repurchase goal through consumer loyalty and doesn't further research the connection between measurements in administration quality or E-Service Quality and 
repurchase goal and consumer loyalty. This examination is just to gauge the connection among factors while the connection among measurements in the factors isn't additionally estimated. In this manner, the scientist prescribes a further exploration to gauge the connection and impact of every e-administration quality measurement to repurchase aim and consumer loyalty.

\section{References}

Al-dweeri, R. M., Obeidat, Z. M., \& Al-dwairi, K. M. (2019). The effect of e-service quality on Jordanian student's e-loyalty: an empirical study in online retailing. International Management of Data Systems, 119(4), 902-923.

Ali, A., \& Bhasin, J. (2019). Understanding Costumer Repurchase Intention in E-commerce: Role of Perceived Price, Delivery Quality, and Perceived Value. Jindal Journal of Business Research, 8(2), 142-157.

Amjad-ur-Rehman, M., Qayyum, A., \& Javed, B. (2019). The Role of Online Shopping Service Quality in e-retailing towards Online Shopping: Testing the moderation mechanism in UTAUT. Pakistan Journal of Commerce and Social Sciences, 13(3), 680-703.

Bressolles, G., \& Nantel, J. (2008). The measurement of electronic service quality: Improvements and application. International Journal of E-Business Research, 4(3), 1-16,19.

Candra, S., \& Juliani, M. (2018). Impact of E-Service Quality and Customer Value on Customer Satisfaction in LocalBrand. Binus Business Review, 9(2), 125-132.

Collier, J. E., \& Bienstock, C. C. (2006). Measuring service quality in e-retailing. Journal of Service Research, 8(3), 260-275.

Davison, R. M. (2017). Economic and Social Satisfaction of Buyers on Consumer -to- Consumer Platforms: The Role of Relational Capital. International Journal of Electronic Commerce, 21(4), 219-248.

Driver, T., Tait, P., Saunders, C., Dalziel, P., Guenther, M., \& Rutherford, P. (2020). Examining Developed versus Emerging Economy Online Food and Beverage Purchase Behaviour and Predictors: A Survey Comparison of Indian, Chinese, Indonesian, Japanese and United Kingdom Consumers. South Asian Journal of Social Studies and Economics, 26-38.

Fornell, C. (1992). A national customer satisfaction barometer: The Swedish experience. Journal of Marketing, 56(1), 6-21.

Goutam, D., \& Gopalakrishna, B. (2018). Customer loyalty development in online shopping: An integration of e-service quality model and commitment-trust theory. Management Science Letters, 8(11), 1149-1158.

Giantari, I. G. A. K., YASA, N. N. K., SUKAWATI, T. G. R., \& SETINI, M. (2021). Student satisfaction and perceived value on word of mouth (WOM) during the COVID-19 pandemic: An empirical study in Indonesia. The Journal of Asian Finance, Economics and Business, 8(6), 1047-1056.

Kotler, P. (2000). Marketing management, millenium edition. Prentice-Hall, Inc.

Kalia, P., Arora, D. R., \& Kumalo, S. (2016). E-service quality, consumer satisfaction and future purchase intentions in e-retail. E-Service Journal, 10(1), 24-41.

Lin, J., Yan, Y., \& Chen, S. (2017). Understanding the impact of social commerce website technical features on repurchase intention: a Chinese guanxi perspective. Journal of Electronic Commerce Research, 18(3), 225.

Liu, T. (2012). Effect of E-service quality on customer online repurchase intentions. ProQuest Dissertations \& Theses Global.

Liu, Yi \& Xinlin Tang (2018) The effect on online trust-building mechanismes on trust and repurchase intentions An Empirical study on eBay. (2018). Information, Technology \& People, 31(3), 666-687. doi: 10.1108/ITP-102016-0242

Miandari, G. A. K. D. D., Yasa, N. N. K., Wardana, M., Giantari, I. G. A. K., \& Setini, M. (2021). Application of Technology Acceptance Model to Explain Repurchase Intention in Online Shopping Consumers. Webology, 18(1).

Parasuraman, A., Zeithaml, V. A., \& Malhotra, A. (2005). ES-QUAL: A multiple-item scale for assessing electronic service quality. Journal of service research, 7(3), 213-233.

Santouridis, I., \& Kyritsi, M. (2014). Investigating the determinants of internet banking adoption in Greece. Procedia Economics and Finance, 9, 501-510.

Suhartanto, D., Helmi Ali, M., Tan, K. H., Sjahroeddin, F., \& Kusdibyo, L. (2019). Loyalty toward online food delivery service: the role of e-service quality and food quality. Journal of foodservice business research, 22(1), 81-97.

Song, C., Brown, H. T., \& Tameez, R. R. (2020). The effectiveness of perceived social support in discount stores in Korea. Asia Pacific Journal of Marketing and Logistics.

Spyridou, A. (2017). Perceived Service Quality and Customer Revisiting Intention: The Case of" all you can eat" Asian Restaurants in Southern Taiwan. Journal of Tourism, Heritage \& Services Marketing, 3(2), 30-38.

Sullivan, Y. W., \& Kim, D. J. (2018). Assessing the effects of consumers product evaluations and trust on repurchase intention in e-commerce environments. International Journal of Information Management, 199-219.

Wang, C., \& Teo, T. S. (2020). Online service quality and perceived value in mobile government success: An empirical study of mobile police in China. International Journal of Information Management, 102076.

Wang, A. G. (2015). E-service quality perceptions: an empirical analysis of the Chines e-retailing industry. Total Quality Management, 26(12), 1357-1372.

Wilson, N., Keni, K., \& Tan, P. H. P. (2019). The effect of website design quality and service quality on repurchase intention in the ecommerce industry: A cross-continental analysis. Gadjah Mada International Journal of Business, 21(2), 187.

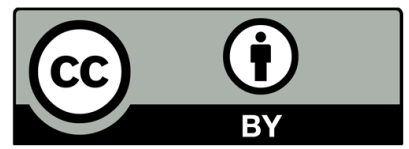

(C) 2022 by the authors; licensee Growing Science, Canada. This is an open access article distributed under the terms and conditions of the Creative Commons Attribution (CC-BY) license (http://creativecommons.org/licenses/by/4.0/). 